\title{
Conditional Harmony: The Relations between Mining Company and Local People
}

\section{Keselarasan Bersyarat: Relasi Perusahaan Tambang dengan Masyarakat Lokal}

\author{
Gilang Mahadika \\ Universitas Gadjah Mada \\ Email: gilangmahadika@mail.ugm.ac.id
}

\begin{abstract}
Mining corporation plays a role as surrogate state since it takes after the state in its development agenda. One of the biggest coal mining companies in Indonesia, PT. KPC (Kaltim Prima Coal), has carried out several activities other than mining ones. The activities are manifested in CSR (Corporate Social Responsibility) programs. An obligation to recover post-mining area by KPC is already implemented in a program called PESAT (Integrated Cattle Farm) which is one of the CSR programs. The farm in the recovered post-mining area is developed as a social program for people living around the mining area. My research was carried out with qualitative approach. Participatory observation and interviews with people in the village of Swarga Bara, Kutai Timur, East Kalimantan, were used in collecting data. The result shows that the people living around the KPC is an active agent in responding the corporate lives. The local people, in fact, depend on the KPC's social programs since the programs are in favor of local development and welfare. Nevertheless, the local people respond negatively toward programs which do not meet their needs.
\end{abstract}

Keyword: mining, coal, corporate social responsibility, post-mining area, corporation

\begin{abstract}
ABSTRAK
Korporasi tambang berperan sebagai surrogate state karena perannya seolah seperti negara dalam mencanangkan agenda pembangunan. Salah satu korporasi tambang batu bara terbesar di Indonesia, PT. KPC (Kaltim Prima Coal), telah berupaya berperan aktif dalam kegiatan-kegiatan di luar aktivitas menambang. Kegiatan pembangunan tersebut diimplementasikan dalam bentuk program CSR (Corporate Social Responsibility). Kewajiban mereklamasi lahan pascatambang juga telah diupayakan oleh KPC menjadi sebuah peternakan yang disebut PESAT (Peternakan Sapi Terpadu). Peternakan di lahan pascatambang tersebut dikembangkan sebagai program sosial (CSR) kepada masyarakat di sekitar tambang. Penelitian ini dilakukan dengan pendekatan kualitatif. Metode wawancara dan observasi-partisipasi pada masyarakat di Desa Swarga Bara, Kutai Timur, Kalimantan Timur digunakan sebagai upaya pengumpulan data. Hasil penelitian menunjukkan bahwa masyarakat yang hidup di sekitar KPC adalah agen yang aktif dalam merespons dinamika kehidupan korporasi tambang. Masyarakat ternyata bergantung pada program tanggung jawab sosial yang diberikan oleh KPC karena membantu program pembangunan wilayah setempat dan kesejahteraan masyarakatnya. Namun, masyarakat juga merespons negatif atas program yang tidak berjalan sesuai dengan kebutuhan mereka.
\end{abstract}

Kata Kunci: Tambang, Batu Bara, Corporate Social Responsibility, Lahan pasca-Tambang, Korporasi 


\section{PENDAHULUAN}

Pertambangan dan kaitannya dengan studi pembangunan menjadi hal yang penting untuk melihat relasi antara pemerintah, korporasi tambang, dengan masyarakat lokal. Relasi di antara mereka pada umumnya tidak harmonis (selaras). Studi pembangunan melalui sektor pertambangan ini seringkali ditemui adanya gesekan, resistensi (perlawanan), dan konflik antara masyarakat lokal dengan korporasi tambang. Misalnya, Sawyer dan Gomez (2012: 6-7) mengembangkan konsep yang telah ditawarkan oleh Michel Foucault dan berusaha mengembangkannya kembali menjadi 'transnational governmentality' sebagai usaha untuk melihat pihak-pihak yang beragam dan keterhubungan masing-masing pihak tersebut dalam mengelola industri ekstraktif (pertambangan) yang tersebar di berbagai negara. Karolien Van Teijlingen dalam tulisannya yang berjudul The 'will to improve' at the mining frontier: Neo-extractivism, development and governmentality in the Ecuadorian Amazon (2016), menyajikan diskursus pemerintahan dalam relasinya antara pertambangan dan pembangunan yang menjadi fitur menonjol dalam masyarakat Ecuadorian, Amazon. Respons masyarakat lokal selalu bertentangan terhadap upaya ekspansi luar biasa dari kebijakan pemerintahan. Misalnya, digambarkan dari beberapa komunitas Shuar yang terlibat dalam counter-conduct (tindakan perlawanan) terhadap proyek pembangunan dari pemerintah melalui sektor pertambangan. Mereka juga memiliki perbedaan dalam memaknai wacana Buen Vivir yang dicanangkan oleh pemerintah. Mereka memaknainya sebagai hidup yang bebas, tanpa ada yang mengganggu. Sedangkan, makna dari pemerintahan sendiri adalah sebagai kesejahteraan (ekonomi). Hal ini berbeda dari bagaimana penduduk setempat memaknai pembangunan tersebut. Maka dari itu, sebuah kehadiran korporasi tambang yang didukung pemerintah terkadang dapat memberikan dampak dan pemaknaan yang berbeda di masyarakat.

Studi kasus lain juga terjadi di Bolivia dalam riset yang dilakukan oleh Thomas Perreault mengenai kemunculan korporasi gas alam (natural gas) dan interseksionalitas (persimpangan) yang terjadi di antara relasi pemerintah transnasional, negara, korporasi, dan dengan masyarakat Guarani (Perreault, 2012: 85). Masyarakat Guarani dianggap sebagai masyarakat asli (indigenouse groups) terbesar keempat sesudah Quechua, Aymara, dan Chiquitanos di Bolivia, dengan menggantungkan pada pertanian subsisten dan semi-subsisten, tetapi mereka perlu hidup berdampingan dengan korporasi tambang gas alam, seperti perusahaan Maxus-Repsol YPF (Perrault, 2012: 87-88). Namun, hal yang menarik adalah bahwa perusahaan gas tersebut berusaha membangun relasi dengan masyarakat Guarani seperti memberikan layanan dasar, seperti pos kesehatan, perumahan, material bangunan, dan lain sebagainya yang hingga menghabiskan beberapa dollar untuk masyarakat Guarani (Perrault, 2012: 88-89). Tetap saja tidak dapat luput dari protes skala kecil dari masyarakat Guarani karena permasalahan lingkungan dan sosial yang dimunculkan perusahaan tambang. Mereka melakukan protes dengan cara memblokade suplai makanan untuk para pekerja tambang tersebut dan juga mengancam korporasi dengan menghentikan aliran gas ke Brazil dengan mengontrol pipa-pipa yang telah dibangun dan mencoba mematikan pipa-pipa tersebut (Perreult, 2012: 90).

Maka dari itu, beberapa kasus tersebut menunjukkan bahwa tidak sekadar karena dampak lingkungan yang membuat perpecahan, melainkan juga terdapat permasalahan yang lebih kompleks yang dapat dilihat dalam konteks kewargaan (citizenship), pembangunan nasional, dan distribusi kekayaan sumber daya. Namun, yang menarik dari sini adalah perhatiannya tidak hanya pada sektor pertambangan yang diunggulkan demi pembangunan nasional, melainkan juga terdapat mobilisasi politik masyarakat lokal yang merepresentasikan diri mereka sendiri sebagai agen yang tidak dipandang pasif dalam memaknai atau merespons gejala yang terjadi di sekitarnya.

Studi kasus lain mengenai pertambangan juga sudah mulai menunjukkan kisah perusahaan

tambang di Amerika Latin yang memberikan perhatian lebih pada CSR (Corporate Social 
Responsibility), karena CSR dapat memitigasi dan mengurangi risiko kemunculan konflik yang berhubungan pertambangan terkait dampak sosial dan lingkungan. Namun, Warnaars (2011) melihat tindakan sebaliknya seperti yang terjadi pada salah satu korporasi di El Pangui, Corriente Resources, yang berupaya membangun ECSA (Corriente Resources' Ecuadorian Subsidiary) dan mengembangkan program CSR dengan istilah "fair deal", yang mana perusahaan merancang dan mengimplementasikan beberapa strategi menjalin relasi dengan komunitas setelah mengidentifikasi kebutuhan komunitas lokal. Berikutnya, ECSA menyajikan perlakuan adil terhadap lingkungan, dengan menciptakan "pembibitan pohon" untuk membantu menghutankan kembali area yang terkena proyek pertambangan (Warnaars, 2011: 7).

Perusahaan juga membangun kebun raya (botanical garden) sebagai cara mereka berkontribusi pada pengetahuan ekologis dan mendukung mitigasi dampak lingkungan dan sosial tertentu di hutan selama proyek pembangunan Mirador berlangsung (Warnaars, 2011: 7). Namun, proyek ini melahirkan keraguan bagi penduduk lokal mengenai niat dari perusahaan, sejak proyek CSR ESCA dilakukan di area kota San Marcos, dan rupanya mengharuskan relokasi kota tersebut karena kota tersebut menjadi area tailings (limbah tambang). Selain itu, tanda jalan yang mengarah ke Kebun Raya tersebut berdekatan dengan kamp pertambangan yang dipasang di depan tanda peringatan bahaya, yang mana Kebun Raya tersebut tidak ditanggapi secara serius, dan penduduk lokal menganggapnya sebagai lelucon dan tidak paham mengapa perusahaan tersebut membangun itu. Petani dan orang asli setempat memiliki tanaman dan bunga yang sama di lahan mereka sendiri. Mereka pun tidak percaya bahwa kebun dan pembibitan pohon tersebut dapat memitigasi dampak lingkungan dari pertambangan skala besar di hutan (Warnaars, 2011: 7).

Perusahaan tambang telah mengupayakan program CSR sebagai tanggung jawab mereka dari aktivitas ekstraksi-eksploitatif agar memperoleh stigma "positif" di masyarakat. Namun, terlihat dari kasus tersebut ternyata CSR dapat menjadi strategi korporasi dalam membangun citra perusahaan yang peduli dengan lingkungan, meskipun menjadi hal yang dianggap tidak memberi pengaruh besar bagi masyarakat sekitar tambang. Dari kasus ini pula sudah mulai terlihat bagaimana korporasi tambang tidak dapat hanya bekerja untuk memaksimalkan profit atau menjalankan bisnis eksploitatifnya, melainkan mereka juga dituntut memiliki banyak aktivitas di luar pertambangan, seperti dalam hal ini kemunculan kesadaran akan melestarikan lingkungan.

Di Indonesia, penting juga untuk melihat korporasi tambang dalam hubungannya dengan kehidupan masyarakat lokal yang tinggal di sekitar lokasi penambangan. Program pembangunan konvensional dari pemerintah --seperti menarik pajak dari beberapa korporasi demi pendapatan negara, kemudian dana tersebut dialokasikan untuk proyek pembangunan bagi warga negara-dirasa secara moral bermasalah. Pasalnya, pendapatan tersebut ternyata hanya untuk memperkaya elite birokrat melalui praktik korupsi dan cenderung memarginalkan penduduk Indonesia secara umum (Welker, 2014: 70). Maka dari itu, perlu adanya bentuk pembangunan alternatif, atau seringkali disebut pembangunan berkelanjutan, yang diupayakan oleh beberapa korporasi tambang dengan skema CSR (Corporate Social Responsibility). Istilah yang disebut pembangunan berkelanjutan ini juga dapat ditafsirkan sebagai model neoliberal, karena perusahaan berupaya mendekatkan diri kepada masyarakat di sekitar tambang sebagai wujud kepedulian dan tanggung jawab perusahaan, sekaligus sebagai strategi agar korporasi tambang dapat menjalankan bisnisnya dengan aman dan berkelanjutan, serta tidak terjerat dalam belitan relasi yang erat dengan masyarakat lokal yang terus bergantung pada korporasi, sehingga masyarakat dapat bekerja secara mandiri (Welker, 2014: 70-71). 
Salah satu perusahaan tambang batu bara di Indonesia, PT KPC (Kaltim Prima Coal), yang menjadi perhatian dalam artikel ini memiliki sebuah visi yang mana mereka menyebutnya sebagai filosofi, yaitu "More than Mining" (tidak sekadar menambang),

Sebagai salah satu produsen batu bara terbesar, KPC percaya bahwa apa yang kami lakukan di sini adalah "Tidak sekedar menambang"- "More than Mining". Kami yakin jika kegiatan penambangan batu bara dikelola dengan bertanggung jawab, batu bara dapat memberikan keuntungan jangka panjang bagi masyarakat, dan di saat yang bersamaan mampu meminimalisasi dampak negatifnya (Sustainability Report KPC, 2017: 35).

Hal tersebut memiliki arti bahwa kegiatan-kegiatan di luar aktivitas menambang secara umum akan dikembangkan menjadi program CSR oleh KPC, seperti pembuatan dan perbaikan jalan di setiap gang (semenisasi), memanfaatkan lahan pascatambang, dan lain sebagainya (Sustainability Report KPC, 2016: 139). Perlu diketahui pula, melalui program CSR tersebut KPC tidak hanya sekadar mengemban kewajiban perusahaan dalam menjalankan tanggung jawab sosialnya, melainkan juga mendukung aktivitas pembangunan infrastruktur dan berupaya memberdayakan masyarakat yang hidup di sekitar perusahaan.

KPC dengan visinya "More than Mining" memberikan keberadaan analogi menarik apabila dikaitkan dengan negara yang memiliki sifat keabstrakannya (kedaulatan) yang menjadi pegangan untuk melancarkan kegiatan-kegiatannya yang didasarkan pada sistem ide tersebut. Bentuk relasirelasi materialnya, mulai dari fase sebelum menambang, fase menambang, setelah menambang, dan kegiatan di luar menambang seperti usaha pemberdayaan masyarakat (program CSR), serta kegiatan-kegiatan lain yang dilakukan oleh perusahaan tambang, menyandarkan pada pedoman ide tersebut (Welker, 2014: 3).

Program-program CSR dari KPC ini ditengarai mencirikan perusahaan yang juga memberi dukungan pembangunan bagi masyarakat yang hidup di sekitar tambang, seperti pembangunan jalan, pemberdayaan masyarakat melalui pemanfaatan lahan pascatambang, dan lain sebagainya. Dengan begitu, perusahaan dipandang sebagai bentuk patronase dan model surrogate state ("wakil negara" /"negara dalam negara") yang memberikan dukungan-dukungan infrastruktur, kemitraan (partnership), dan lain sebagainya, kepada masyarakat yang hidup di sekitar tambang (Welker, 2014: 69), di saat masyarakat sendiri juga sulit menggantungkan pada pembangunan konvensional pemerintah Indonesia yang dianggap secara moral bermasalah.

Masyarakat lokal yang hidup di sekitar tambang dalam kasus lain tidak selamanya melakukan perlawanan (resistensi), melainkan mereka berperan aktif dalam berupaya agar dapat mengakses sumber daya yang berada dalam perusahaan. Misalnya, masyarakat Sumbawa (di Desa Tongo) menjadi bergantung kehidupannya pada korporasi Newmont (Welker, 2009, 2014). Bahkan, secara implisit masyarakat mendukung keberadaan Newmont di Sumbawa. Salah satu kasusnya adalah ketika masyarakat lokal menentang NGO (Non-governmental Organization) atau LSM (Lembaga Swadaya Masyarakat) yang memprotes Newmont karena permasalahan lingkungan. Masyarakat tersebut memasang spanduk yang bertuliskan, "Masyarakat Sekongkang menentang apapun bentuk Aksi Teror terhadap PT. NNT" (Newmont Nusa Tenggara). Mereka mengklaim bahwa LSM telah meremehkan mereka karena LSM tidak meminta persetujuan terlebih dahulu kepada pejabat lokal dari desa dan kecamatan (Welker, 2009: 164). Seolah masyarakat Sekongkang mengingatkan kepada orang dari luar (outsiders) bahwa pertambangan Newmont berada di bawah perlindungan masyarakat lokal sendiri. Melihat kasus ini, masyarakat seolah menjadi pelindung (defenders) bagi korporasi Newmont karena korporasi berupaya mendistribusikan kekayaannya kepada masyarakat sekitar dalam skema CSR sebagai bentuk pembangunan masyarakat sekitar tambang.

Kembali pada kasus KPC, kegiatan di luar pertambangan perusahaan ini juga terlihat begitu beragam. Bahkan, menariknya, salah satunya seperti upaya perusahaan dalam memanfaatkan kembali lahan pascatambang (post-mining) yang memberikan kebermanfaatan ekonomi yang 
berbeda, di luar sektor pertambangan. Satu dari beragam kegiatan perusahaan KPC di luar pertambangan adalah membangun program Peternakan Sapi Terpadu di lahan seluas 22 hektar, dan masyarakat yang hidup di sekitar tambang mengenalnya dengan sebutan PESAT. PESAT diharapkan dapat menjadi percontohan bagi perusahaan lain dalam pemanfaatan lahan pascatambang demi pembangunan berkelanjutan (Sustainability Report KPC, 2016: 128).

Mengambil istilah dari David Biggs (2018), creative destruction, sebuah "kerusakan yang kreatif" justru menghasilkan peluang ekonomi lain, seperti halnya aktivitas tambang batu bara yang menghasilkan dampak kerusakan lingkungan dapat dipulihkan kembali menjadi suatu alternatif ekonomi yang baru. Mengingat bahwa kegiatan reklamasi sebenarnya sudah diatur dalam Keputusan Menteri No. 18 tentang Reklamasi dan Penutupan Tambang 2008 Indonesia (Devi dan Prayogo, 2013: 33), hal tersebut sudah menjadi tanggung jawab bagi perusahaan tambang mineral dan batu bara (environmental responsibility) untuk melakukan reklamasi atau pemulihan kegiatan setelah menambang. Menariknya, tindakan reklamasi ini dapat dimanfaatkan kembali untuk kegiatan ekonomi lain dan dijadikan sebagai strategi program tanggung jawab sosial perusahaan (CSR) untuk memberdayakan masyarakat lokal yang hidup di sekitar tambang dalam wujud jalinan kemitraan suplai pakan ternak PESAT dengan para petani di sekitar tambang.

Perusahaan tambang di Indonesia wajib melaksanakan apa yang diamanatkan dalam pasal 74 Undang-Undang Nomor 40/2007 tentang Perseroan Terbatas (UUPT) mengenai kewajiban perusahaan untuk mengeluarkan program pemberdayaan masyarakat (program CSR) dan kewajiban dalam melakukan reklamasi atau pemulihan lahan setelah aktivitas pertambangan (Devi dan Prayogo, 2013: 33, 37). Pemberian program sosial dan lingkungan ini menjadi suatu yang penting bagi perusahaan tambang untuk mengkonstruksi citra atau wajah lain yang lebih positif (Welker, 2014: 4), sampai pada akhirnya perusahaan dipandang sebagai agen pembangunan layaknya pemerintah-negara.

\section{METODE PENELITIAN}

Penelitian terhadap masyarakat di Desa Swarga Bara, Kecamatan Sangatta Utara, Kabupaten Kutai Timur, Provinsi Kalimantan Timur telah dilakukan untuk menjawab rumusan masalah mengenai program CSR KPC, dan upaya perusahaan KPC memanfaatkan lahan pascatambang menjadi PESAT (Peternakan Sapi Terpadu) dengan respons komunitas terdampak pertambangan di sekitar desa Swarga Bara. Desa ini juga menjadi housing quaters perusahaan KPC (Lahiri-Dutt dalam Borges dan Torres [ed], 2012: 212). Metode penelitian dilakukan dengan pendekatan kualitatif, dalam artian bahwa data yang dikumpulkan terutama karena menggunakan teknik wawancara informal dan observasi partisipasi dengan masyarakat (Brewer, 2000: 35). Penelitian ini juga berupaya mengombinasikan (combined) atau mencampurkan (mixed) data kualitatif yang menjadi pendekatan utama, kemudian dibantu oleh data kuantitatif yang diperoleh dari hasil penelitian. Alasan menggunakan data kuantitatif sebagai ilustrasi (tabel) untuk memperoleh objektivitas dari suatu data, kemudian keterbatasan dari kuantitatif diisi menggunakan data kualitatif sebagai upaya menangkap persepsi masyarakat dalam menghadapi suatu fenomena (Brewer, 2000: 31-35). Pemaparan hasil penelitian dilakukan secara narasi-deskriptif seperti metode etnografi pada umumnya. Kemudian, secara langsung dianalisis menggunakan kerangka berpikir yang telah digunakan oleh peneliti dalam melakukan penelitian (Hammersly dan Atkinson, 2007: 159).

Peneliti melakukan penelitian terbuka mulai dari bulan Januari sampai Februari 2019 sebagai cara untuk membangun kepercayaan dengan komunitas terdampak pertambangan (Hammersley dan Atkinson, 2007: 63). Peneliti mulai memberitahu dan memperkenalkan diri sebagai akademisi yang sedang melakukan penelitian. Setelah itu, melakukan impression management (Hammersley dan Atkinson, 2007: 67) sebagai cara untuk diterima oleh masyarakat Swarga Bara melalui penampilan dan mempelajari bahasa mereka, walaupun tidak secara utuh mengubah bahasa yang menjadi latar belakang peneliti.

Observasi dan wawancara sebagai cara peneliti untuk memperoleh data penelitian dimulai dengan percakapan informal pada awal penelitian lapangan sebagai cara melebur dengan para 
informan (Hammersley dan Atkinson, 2007: 70). Dua konsep Junker dan Gold dalam Hammersley dan Atkinson (2007: 85), yakni participant-as-observer dan observer-as-participant sebagai cara peneliti untuk merefleksikan diri yang memiliki pandangan eksternal (latar belakang pengetahuan) untuk mendapatkan perspektif masyarakat dengan menafsirkan apa yang dilakukan oleh para informan di Desa Swarga Bara.

Teknik memilih informan berdasarkan tipologi Dean dalam Hammersley dan Atkinson (2007: 106), yang pertama adalah informants who are specially sensitive to the area of concern (para informan yang terutama sensitif terhadap wilayah yang menjadi perhatian), yakni mereka yang secara alami dan objektif melihat persoalan tersebut seperti Kepala operasional tiga lahan pascatambang (Supv. Specialist Conservation and Development), Kepala Pabrik Pakan Mini (mini feedmill) PESAT, bagian CAD (Conservation, Agribusiness, and Development) dari Departemen Community Empowerment KPC, bagian PMD (Post-Mining and Development) dari Depatermen Community Empowerment KPC, dan specialist learning management dari Departemen Learning and Development (LND) KPC. Peneliti telah diarahkan oleh LND untuk menemui user (informan) di dalam Community Empowerment KPC yang sesuai dengan kebutuhan penelitian, sehingga peneliti dibatasi untuk mengakses informan yang ada di dalam satu departemen Community Empowerment KPC.

Kedua adalah the-more-willing-to-reveal informants (para informan yang memiliki niat lebih untuk mengungkapkan sesuatu) (Hammersley dan Atkinson, 2007: 107), yakni para informan yang memiliki latar belakang atau status yang lebih memiliki niat untuk berbicara daripada yang lain; mereka adalah komunitas terdampak pertambangan, seperti orang-orang bermata pencaharian di luar pertambangan, antara lain ketua kelompok tani, ketua RT Kampung Jawa, Desa Swarga Bara, ketua gabungan kelompok tani, PPL (Penyuluh Pertanian Lapangan) dari Dinas Pertanian pemerintah daerah yang bertempat di Desa Swarga Bara, petani pemilik lahan, dan pekerja kasar dua lahan pascatambang, serta pemerintahan desa --kepala desa, sekretaris desa, Badan Permusyawaratan Desa (BPD), dan Direktur BUMDes Swarga Bara. Hal ini digunakan untuk mengetahui pengelolaan program CSR yang dikeluarkan KPC, terutama dalam memanfaatkan lahan pascatambang PESAT. Sesuai dengan etika dalam penelitian, nama masyarakat (powerless group) dalam paparan laporan penelitian akan disamarkan sebagai bentuk upaya melindungi para informan yang tak memiliki kuasa untuk mengatur; mereka adalah informan yang termasuk dalam kategori kedua ini, the-more-willing-to-reveal-informants. Para elite desa tetap diupayakan disamarkan sebagai bagian dari masyarakat yang terdampak oleh program pemberdayaan dari perusahaan KPC.

Data primer yang dianalisis juga akan diperkuat dengan data sekunder dari berita-berita melalui media berita resmi dari pemerintah dan laporan penelitian terdahulu seperti penjelasan mengenai Alokasi Dana Desa (ADD), Dana Desa (DD), Forum MSH-CSR, dan lain sebagainya. Hal ini dikumpulkan untuk melihat dinamika kebijakan dan pembangunan dari tingkat pemerintah lokal dan masyarakat di sekitar tambang, serta membantu melihat penemuan data seputar CSR. Hal ini dimanfaatkan oleh peneliti untuk memeroleh gambaran isu di tingkat lokal, dan akan dibandingkan dengan data primer hasil dari observasi dan wawancara di Desa Swarga Bara. Dengan keterbatasan peneliti untuk memperoleh data mengenai pemerintah Kutai Timur, data sekunder ini menjadi acuan untuk mendukung apa yang terjadi di lapangan (melalui data primer). Salah satunya seperti di saat Musrenbangdes (Musyawarah Perencanaan Pembangunan Desa) Swarga Bara tidak memperoleh ADD (Alokasi Dana Desa) dari pemerintah daerah, mereka pun mengandalkan pihak ketiga (perusahaan KPC) melalui program CSR sebagai ganti ADD yang kosong, ditambah pemerintah desa juga mengandalkan DD (Dana Desa) yang langsung dari pemerintah pusat. Contoh lain, seperti membangun PESAT (Peternakan Sapi Terpadu) di lahan pascatambang KPC, tidak serta-merta dibangun begitu saja, tetapi perlu menyesuaikan dengan kebutuhan swa-sembada daging sapi dari perencanaan pemerintah daerah. Mengingat perusahaan-perusahaan tambang di Kutai Timur masuk dalam Forum MSH-CSR (Multistakeholders for CSR), segala program CSR harus disinkronkan dengan kebutuhan pemerintah daerah. 


\section{HASIL DAN PEMBAHASAN}

Dikarenakan Anggaran Dana Desa (ADD) yang tidak cair, para kepala desa yang mengadakan pertemuan dengan pihak pemerintah Kabupaten Kutai Timur (pada Januari 2019) mengancam untuk menghentikan pelayanan kepada masyarakat karena ketiadaan anggaran untuk operasional kantor desa. Namun, pemerintah Desa Swarga Bara tetap berupaya menampung usulan-usulan dari para Ketua RT (Rukun Tetangga) yang ada di desa tersebut. "ADD kita nihil, operasional saja tidak didayakan karena sedikit. Usulan-usulan pak RT dan pihak lainnya tetap kita akan perjuangkan, dan kita akan cover," Kepala Desa Swarga Bara.

Utang yang berlebih mengakibatkan Desa Swarga Bara tidak memiliki ADD (Alokasi Dana Desa) yang dikeluarkan oleh pemerintah daerah melalui APBD (Anggaran Pendapatan dan Belanja Daerah) (Sari, dkk 2015: 1881). Menurut Kepala Desa, tidak adanya ADD membuat desa juga tidak dapat memberdayakan operasional desa, sehingga ketika pemerintah desa mengajukan usulan skala prioritas untuk pembangunan desa, dari tingkat desa hingga tingkat kabupaten juga tidak akan membuahkan hasil karena tidak adanya anggaran dana dari pemerintah daerah.

Bahkan, salah satu warga Swarga Bara berupaya mempertanyakan mengenai distribusi raskin (beras miskin) dari pemerintah yang rupanya tidak tepat sasaran. Kemudian, pihak kecamatan pun angkat bicara dengan mengatakan, "Data yang dipakai oleh BPS (Badan Pusat Statistik) itu data 2011, mungkin ada yang sudah meninggal atau sudah naik taraf hidupnya." Pernyataan tersebut menuai respons negatif dari beberapa warga yang terlibat dalam musyawarah desa ini, dengan mengatakan, "Kasihan jatah orang miskin diambil yang mampu." Pemerintah Desa Swarga Bara di sini juga tidak diam saja dan berupaya mengklarifikasi apa yang terjadi mengenai distribusi tersebut dengan mengungkapkan kekesalannya terhadap pemerintah daerah. "Raskin sebenarnya sudah berusaha kami sortir dan kenapa tidak dibagi-bagi? Karena ini tidak tepat sasaran bagi yang tidak mampu, dan datangnya sendiri dari dinas sosial, padahal desa yang lebih tahu bagaimana masyarakatnya," singgung pemerintah desa. Kelalaian pemerintah ini pun membuat masyarakat desa ini menjadi semakin tidak percaya pada kinerja pemerintah dan sulit untuk kembali menggantungkan diri mereka pada aparatus negara.

Menariknya, dari Musrenbangdes (Musyawarah Perencanaan dan Pembangunan Desa) 2019 yang diadakan di kantor desa, kepala desa mengatakan bahwa sumber-sumber dana tidaklah hanya dapat diperoleh melalui pengajuan pendanaan ke pemerintah daerah atau pusat, melainkan juga dapat diperoleh melalui pihak ketiga. Pihak ketiga tersebut adalah perusahaan-perusahaan tambang, seperti KPC. Program-program yang dikeluarkan oleh perusahaan berupa program CSR dianggap termasuk ke dalam sumber dana lain dari pihak ketiga. Namun, kepala desa pun tetap berusaha memperjuangkan melalui dana dari pemerintah pusat melalui APBN (Anggaran Pendapatan Belanja Negara), yaitu berupa Dana Desa (DD) (Meutia dan Liliana, 2017: 336) yang nantinya dapat digunakan sesuai dengan kebutuhan tiap-tiap RT yang ada di Desa Swarga Bara.

“Tapi kita juga artinya tidak berputus asa, karena ada sumber-sumber dana yang lain mungkin yang bisa kita harapkan agar dapat digunakan, tergabung dari pihak CSR atau dari pihak ketiga. Pemerintah desa yang melalui Dana Desa (DD) kita alokasikan ke tiap-tiap RT sesuai dengan yang kita jalankan selama ini," Kepala Desa.

KPC telah memberikan bantuan program-program CSR dalam wujud infrastruktur, seperti pembuatan jalan (semenisasi) di beberapa gang yang berada di desa. Sehingga apa yang dinyatakan oleh kepala desa tersebut memberikan pandangan mengenai pentingnya pihak ketiga yang dapat memberikan dana demi pembangunan Desa Swarga Bara. KPC melalui laporannya (Sustainability Report KPC, 2017: 126) telah berupaya untuk membangun jalan-jalan yang berada di sekitar Desa

Swarga Bara dengan tujuan untuk mendukung program pemerintah di tingkat desa dari empat kecamatan yang masuk dalam ring satu perusahaan, dan membangun akses jalan merupakan 
infrastruktur terbesar dari seluruh program pengembangan dan pemberdayaan masyarakat yang dilakukan oleh KPC.

Pemerintah daerah (kecamatan) yang turut hadir dalam musyawarah tersebut seolah tidak menjadi perhatian dalam penyusunan skala prioritas pembangunan infrastruktur desa, dan para pengurus desa lebih mencurahkan keluhan yang terjadi di desa kepada karyawan KPC. Alasan ketiadaan anggaran daerah ini membuat desa menggantungkan dirinya pada perusahaan KPC demi terlaksananya pembangunan infrastruktur di Desa Swarga Bara. Dalam musyawarah tersebut, hadir pula sekretaris BPD (Badan Permusyawartan Desa), yang merasa bahwa KPC perlu membantu dalam hal inventaris yang berada di kantor desa, seperti bangku, kursi, dan inventaris lainnya. Pemerintah desa tidak memiliki tempat penyimpanan barang-barang tersebut, sehingga di tengah musyawarah desa tersebut, beberapa warga mengeluh dan mengajukan usulan kepada pihak ketiga (KPC) untuk membantu permasalahan desa terkait dengan barang-barang inventaris Desa Swarga Bara.

"Kebetulan ada karyawan KPC di sini. Kami mohon kalau bisa diusulkan, terus terang, banyak permintaan kami untuk PT KPC. Kami terkendala juga untuk inventaris. Kami mohon kalo bisa dibantu KPC, mohon dibantu, kasihan juga kita punya bangku, tapi banyak yang hilang, karena kita tidak punya penyimpanannya itu."

Di sini terlihat bagaimana perusahaan memiliki peran penting dalam pembangunan infrastruktur desa. Bahkan, dari skala inventaris desa hingga melakukan perbaikan jalan, perusahaan KPC menjadi perusahaan yang dapat mendukung secara finansial bagi pembangunan infrastruktur desa. Saat musyawarah berakhir, dua karyawan KPC yang hadir menjumpai perangkat desa dan mencoba membicarakan lebih lanjut mengenai keluhan-keluhan yang dihadapi oleh pemerintah desa di ruang kantor kepala desa.

Salah satu warga Desa Swarga Bara, ketika ditemui di rumahnya yang jalan di depan rumahnya masih berbatu, akan memperoleh bantuan dari perusahaan KPC berupa pembangunan jalan atau semenisasi, yang meliputi juga jalan di depan rumah sekretaris desa. "Kalau kita diberi bantuan ya seneng, soalnya kayak depan rumah ini mau dibikinin jalan sampai ujung," (Hasil wawancara dengan informan, 10 Februari 2019). Namun rupanya, bantuan pembangunan jalan tersebut masih menjadi perebutan bagi warga sekitar rumahnya, seperti ada yang menuntut untuk dapat memanjangkan semenisasi tersebut hingga ujung jalan Poros Kabo Jaya dengan cara mengurangi ketebalan semen tersebut. "Ada pak RT yang mintanya biar bisa sampai jalan poros, tingkat ketebalannya dikurangin, padahal sudah ada spec-nya," lanjutnya. Pendistribusian yang tidak merata kepada masyarakat desa, dan tindakan yang dilakukan oleh perusahaan seperti pembangunan jalan itu, dikarenakan kebijakan dari pemerintah untuk memberikan tanggung jawab sosial kepada perusahaan, dan perusahaan tidak bertanggung jawab terhadap bagaimana masyarakat mendistribusikan bantuan tersebut di antara mereka (Welker, 2014: 86).

Bagian CAD (Community, Agribusiness, and Development), departemen Community Empowerment KPC, mengatakan bahwa bantuan berupa program CSR seperti pembangunan jalan (semenisasi) adalah upaya yang dilakukan oleh perusahaan, dan itu adalah kewajiban yang perlu ditaati oleh perusahaan, serta yang bertanggung jawab atas pembangunan adalah pemerintah negara. Perusahaan seperti KPC hanya mendukung apa yang dilakukan oleh pemerintah,

"Masyarakat itu kan berbagai macam isi kepalanya dengan berbagai macam harapanharapannya tentunya kan KPC juga tidak menjadi, bukan menjadi satu institusi berkewajiban untuk meningkatkan kualitas hidup mereka. Nah, ini yang perlu dipahami juga, kalau yang punya peran tanggung jawab itu kan negara, pemerintah. Perannya perusahaan melalui KPC kan mendukung apa yang dilakukan oleh pemerintah, sehingga kalau masyarakat masih kurang ini, kurang itu, masih ada isu 
itu, ya itu suatu yang lumrah, suatu yang biasa saja, tapi tidak kemudian semuanya dilempar permasalahan ke KPC," (Hasil wawancara, informan Pak Sugeng bagian CAD, 19 Februari 2019).

KPC membangun infrastruktur karena perintah dari negara untuk melakukan itu. Namun, di sisi lain, terdapat pengakuan dari kepala desa mengenai upaya perangkat desa memperoleh dana CSR dari pihak ketiga tersebut menjadikan perusahaan juga sebagai agen pembangunan penting bagi pembangunan desa. Pemerataan pembangunan jalan di depan rumah warga yang memanfaatkan dana CSR KPC perlu disesuaikan dengan kepentingan para elite desa (seperti depan rumah sekretaris desa yang akan dilakukan semenisasi). Hal ini membuat beberapa RT yang hidup bersama dengan perangkat desa ada yang tidak memperoleh bagian distribusi dana CSR tersebut. Dari sini juga terlihat bagaimana tuntutan masyarakat lokal terhadap program-program CSR yang dikeluarkan oleh perusahaan sangatlah besar.

Program-program CSR perusahaan KPC ini menyiratkan bahwa perusahaan juga memberi dukungan pembangunan bagi masyarakat yang hidup di sekitar tambang, seperti pembangunan jalan, pemberian inventaris, dan lain sebagainya. Dengan begitu, perusahaan juga dipandang sebagai bentuk patronase dan model surrogate state ("wakil negara" /"negara dalam negara") yang memberikan dukungan-dukungan infrastruktur, pelatihan, bantuan, dan lain-lain kepada masyarakat yang hidup di sekitar tambang (Welker, 2014: 69). Apa yang dipandang perusahaan dalam hal ini cenderung sesuai dengan kritik perusahaan yang sifatnya liberal,

Enacting the company as an agent of development, which I characterize as patronage and sustainable development [...] between local views of the company as a "pot of money" and a "set of skills" [...] In the largesse-distributing-patron model of the corporation, the company acts as a surrogate state providing jobs, tangible welfare, and infrastructure to local communities (Welker, 2014: 69).

(Memberlakukan perusahaan sebagai agen pembangunan, yang mana saya cirikan sebagai pemberi bantuan dan pembangunan keberlanjutan [...] antara pandangan lokal mengenai perusahaan sebagai "pot uang" dan "perangkat kemampuan". Dalam model patron perusahaan, perusahaan bertindak sebagai surrogate state yang menyediakan pekerjaan, kesejahteraan yang nyata, dan infrastruktur bagi komunitas lokal).

Mengingat bahwa program CSR menjadi praktik yang seringkali diterapkan oleh korporasi, hal ini juga dapat dimaknai sebagai aktivitas "memoralkan" ekonomi (Dolan dan Rajak, 2011: 5). Kembali pada konsep dari Marcel Mauss mengenai masyarakat manusia yang memiliki kewajiban untuk memberi (obligation to give) (Mauss, 1967: 37), ia memaparkan analogi seperti yang terjadi dalam perusahaan KPC. Mauss melihatnya dari gagasan "wajah/rupa” sebagai orang yang tidak merayakan potlatch (pendistribusian kekayaan yang biasa dilakukan oleh kepala suku dengan merayakan makan bersama atau wujud perayaaan lainnya), maka wajah dari kepala suku yang terhebat pun dapat dipandang seperti memiliki "wajah yang busuk" di mata masyarakat, yang mana dinarasikan dalam bentuk tarian topeng dalam masyarakat Kwakiutl dan Haida (Mauss, 1967: 38). Program-program CSR ini kemudian menjadi representasi atau sarana pemberian "hadiah" dari perusahaan kepada masyarakat lokal. Kemudian, masyarakat lokal secara tidak langsung merekonstruksi citra korporasi yang tidak sekadar melakukan eksploitasi, kerusakan lingkungan karena aktivitas pertambangan, melainkan juga menjadi agen pembangunan bagi masyarakat karena pendistribusian kekayaan perusahaan KPC kepada masyarakat melalui program-program CSR.

Lebih jauh, masyarakat dalam kasus ini juga terlihat lebih menggantungkan bantuan-bantuan pada korporasi KPC ketimbang pada pemerintah-negara. Maka dari itu, hal ini juga dapat dimaknai bahwa masyarakat local memandang korporasi tambang sebagai model patronage 
(perlindungan/langganan tetap) mereka (Welker, 2014: 69). Namun, di sini juga tidak berarti bahwa ciri khas patronase perusahaan adalah pemaknaan satu arah bagi korporasi sendiri, melainkan ide patronase sendiri rupanya dalam kasus ini dikoproduksi oleh penduduk lokal atas ancaman kegiatan korporasi tambang yang merusak lingkungan. Oleh karena itu, upaya korporasi dalam mendukung pembangunan masyarakat lokal juga dianggap sebagai strategi agar dapat terus menjalankan bisnis pertambangan mereka (Welker, 2014: 69). Dengan menjalin relasi layaknya model patron-klien (korporasi tambang dengan masyarakat lokal) melalui beberapa proyek pembangunan terhadap masyarakat lokal, korporasi tambang KPC dapat terus menjalankan operasi pertambangannya tanpa ada gangguan. Model patron-klien ini, seperti halnya sistem kekerabatan, sentimen, affect (emosi), dan ikatan sosial lainnya melalui praktik pemberian "hadiah" (gifting practices) dalam wujud CSR, perlu dilihat sebagai sistem kapitalisme yang "membangun" ketimbang sebaliknya (Granovetter, 1985; Rajak, 2011; Yanagisako, 2002). Aktivitas yang berkontradiksi terhadap logika kapitalisme dalam kasus ini dapat dilihat melalui aktivitas korporasi tambang yang menyedikan bantuan dana CSR kepada masyarakat lokal.

\section{Kemitraan PESAT yang Tidak Berjalan Pesat}

Mengemban kewajiban melakukan reklamasi lahan setelah aktivitas pertambangan seperti yang tertera dalam aturan undang-undang Republik Indonesia bagi perusahaan tambang mineral dan batu bara (Devi dan Prayogo, 2013: 33), perusahaan KPC telah bekerja sama dengan pemerintah untuk melakukan penyusunan dokumen Rencana Penutupan Tambang (RPT) sejak 2011, yang artinya bahwa KPC telah memikirkan masa depan mengenai rencana perizinan pertambangan setelah usaha tersebut berakhir. Dokumen RPT tersebut mencakup aspek-aspek seperti lingkungan, ekonomi yang berfokus pada aktivitas di dalam perusahaan maupun di luar perusahaan. Dokumen RPT perlu mengikuti triple-bottom line (aspek lingkungan, sosial dan ekonomi) yang telah ditetapkan dalam forum MSH-CSR dan dijadikan sebagai acuan dalam mengeluarkan program CSR (program pemberdayaan masyarakat) (Suryanto, 2013: 315). Perusahaan KPC dalam mengupayakan reklamasi tambang dan merencanakan program pemberdayaan masyarakat selalu melandaskannya pada dokumen RPT tersebut. Dalam dokumen tersebut juga dijelaskan mengenai upaya KPC melakukan zonasi yang terdiri dari lima zona, yaitu keanekaragaman hayati (zona konservasi), zona penyangga, zona wisata, zona pemanfaatan, dan zona lindung (Sustainability Report KPC, 2016: 80). Salah satu contoh yang saat ini diterapkan dalam pemanfaatan lahan pascatambang adalah program PESAT (Peternakan Sapi Terpadu), yang di dalam dokumen RPT masuk dalam zona pemanfaatan (utilization zone).

Kegiatan di luar pertambangan tersebut memberikan kebermanfaatan ekonomi yang berbeda. Karena sifatnya di luar kegiatan tambang, hal ini juga dijadikan sebagai program CSR oleh KPC. Menurut Sustainability Report KPC (2016: 128), PESAT diharapkan dapat menjadi porcontohan bagi perusahaan lain dalam pemanfaatan lahan pascatambang demi pembangunan berkelanjutan dengan cara membangun usaha pembibitan sapi, penggemukan sapi, sapi perah untuk memenuhi kebutuhan lokal, dan dapat meningkatkan sumber daya manusia dalam pengembangan peternakan lokal.

Sebuah alur logika berjalannya program PESAT yang dikembangkan oleh perusahaan KPC juga perlu koordinasi dari pemerintah daerah. Alasan dari dibangunnya PESAT tidak hanya mengikuti dokumen RPT yang telah dibuat, tetapi ada upaya menyelaraskan kebutuhan swa-sembada daging bagi masyarakat Kalimantan Timur dikarenakan masih adanya ketergantungan sapi yang diperoleh dari luar Kalimantan,

"Ini semua dalam rangka juga untuk mendukung target swa-sembada daging dan swa-sembada populasi ternak sapi di Kalimantan Timur. Sehingga ada kontribusi ini dari lahan pascatambang yang programnya PESAT untuk mewujudkan itu. Daging itu juga masih ketergantungan dari luar Kalimantan, sehingga kami kembangkan di 
lahan pascatambang" (Hasil wawancara, informan Pak Sugeng Wiyatno bagian CAD Community Empowerment KPC, 19 Februari 2019).

Apabila mengacu pada Sensus Pertanian tahun 2013 (Ariningsih, 2014: 148), terlihat distribusi yang tidak merata daging sapi yang tersebar di Indonesia, yang mana Pulau Jawa dan Sumatera sejumlah 69,06\% dari populasi sapi potong nasional, sedangkan Sulawesi, Kalimantan, Maluku, dan Papua sekitar 16,77\%. Kementerian Pertanian pada tahun 2014 dalam merancang PSDS (Program Swasembada Daging Sapi) mengupayakan untuk menggerakkan dan meningkatkan peran kementerian lain, seperti kementerian BUMN dan ESDM, dalam pemanfaatan dana CSR untuk pengembangan usaha peternakan (Ashari, dkk, 2012: 189). Program Pemerintah Kalimantan Timur yang bertajuk "Program Dua Juta Sapi Tahun 2018" menunjukkan upaya pemerintah untuk menjadikan Kalimantan Timur sebagai sumber ternak nasional, dan pemerintah mengupayakan tidak hanya alokasi APBD saja, tetapi mengandalkan dana CSR dari perusahaan yang dapat memeroleh sekitar 250 ribu ekor sapi, untuk mendukung percepatan swa-sembada daging sapi (Kaltimprov, 2018). Oleh karena itu, PESAT tidak serta-merta dibangun menjadi peternakan sapi tanpa ada sangkut-paut apapun, melainkan melalui forum multi-stakeholders for CSR (MSH-CSR) bersama pemerintah mencoba untuk menyesuaikan dan mengupayakan program pembangunan yang dilakukan pemerintah dapat diimplementasikan dalam program CSR perusahaan KPC.

Dimulai sekitar 2008/2009, ada seorang dosen dari Institut Pertanian Bogor (IPB) yang melakukan penelitian sederhana dalam mengupayakan agar sapi dapat diternakkan di lahan pascatambang. Kemudian, diupayakan pula agar rumput yang berada di lahan pascatambang tersebut dapat dimanfaatkan untuk pakan ternak. Seringkali lahan pascatambang atau bekas galian tambang batu bara memiliki stigma negatif di tengah masyarakat bahwa, misalnya, lahan tersebut tidak dapat digunakan lagi karena mengandung racun, bahkan dianggap sebagai tanah yang marginal yang seolah tidak dapat didayakan kembali. Namun, menurut hasil penelitian tersebut, rumput yang ditanam di lahan pascatambang dapat memberikan dampak yang positif untuk pertumbuhan dan perkembangan sapi bali.

"Kan orang pasti punya mindset bahwa lahan pascatambang setelah dilakukan proses mau mereklamasi itu kan masih punya kemungkinan tanahnya yang mengandung toxic, dianggap tanah yang marginal, macam-macam ya. Sehingga seorang dosen IPB mencoba penelitian, ternyata, singkat cerita, rumput yang ditanam di lahan pascatambang ini memberikan kontribusi positif untuk pertumbuhan, perkembangan daripada sapi bali" (Hasil wawancara, informan kepala CAD, Pak Sugeng Wiyatno, 19 Februari 2019).

Setelah perkembangan dari peternakan sapi tersebut, yang pertama dan paling penting adalah peningkatan kapasitas sumber daya manusia, dan hal ini juga menjawab persoalan untuk melancarkan program pemberdayaan komunitas (masyarakat), dalam artian PESAT menjadi wadah untuk pembelajaran masyarakat, para peternak dan petani di sekitar tambang. Pada awal pendirian PESAT di tahun 2009, KPC berupaya untuk menghubungkannya dengan program pemberdayaan komunitas (community empowerment). Hal tersebut dilakukan agar dapat dimanfaatkan tidak hanya untuk memanfaatkan lahan bekas penambangan, melainkan juga memiliki dampak bagi masyarakat yang berada di sekitar pertambangan, "Sehingga, dari awal berdiri 2009, itu konsep PESAT bagaimana caranya kehadiran ini bisa digandengkan dengan program pemberdayaan, KPC melihat tidak hanya itu, KPC mencoba menggandengkan dengan program sosial (CSR)" (Hasil wawancara, informan kepala operasional lahan pascatambang, Pak Rangga Lawe, 11 Februari 2019).

Yayasan Sangatta Baru (YSB) adalah pengelola peternakan sapi tersebut, yang diletakkan di lahan pascatambang perusahaan KPC, yang mana nantinya hasil dari peternakan sapi dapat dipasarkan tidak hanya di wilayah Sangatta, tetapi di wilayah Kalimantan lainnya, seperti Samarinda dan Balikpapan (Sustainability Report KPC, 2016: 128). Penjualan yang dilakukan oleh YSB hanyalah sebatas HPP (Harga Penjualan Pokok). Dana CSR dari KPC diberikan kepada yayasan 
dalam wujud subsidi untuk pembiayaan operasional, pemberdayaan masyarakat, dan lain sebagainya yang berada di PESAT, "Selama ini kan ada subsidi-subsidi lah ya. KPC itu kan ada bisnis, tidak diambil oleh KPC, tapi di dalam pengelolaan melalui yayasan juga tidak boleh mengambl profit dari kegiatan tersebut, tapi lebih kepada penentuan produksi HPP-nya," (Hasil wawancara, informan Pak Sugeng Wiyatno, kepala CAD KPC , 19 Februari 2019).

Bentuk dari pemberdayaan masyarakat yang dikeluarkan oleh PESAT adalah melakukan kerja sama dengan masyarakat sebagai pemasok pakan sapi ternak atau seringkali disebut program kemitraan. Program kemitraan ini --berjalan sejak 2016-- memiliki 17 mitra kerja yang telah melakukan hubungan kerja sama dengan YSB (Sustainability Report KPC, 2016: 128). "Masyarakat diajak, digandeng untuk menjadi supplier pakan" (Hasil wawancara, informan kepala operasional lahan pascatambang, Pak Rangga, 11 Februari 2019). Pihak PESAT di sini nantinya sebagai wadah bagi masyarakat, sebagai pembeli bahan baku pakan ternak dari masyarakat sekitar tambang, sehingga masyarakat tani pun dapat menjual hasil bahan baku pakan ternak secara terbuka kepada PESAT.

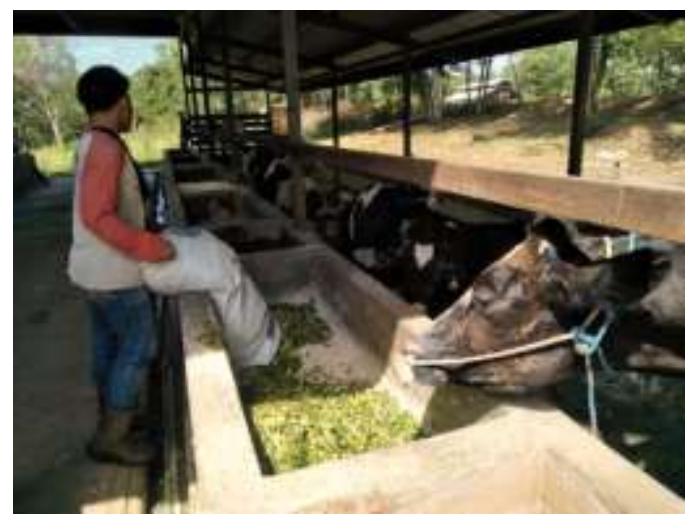

Gambar 1 Pekerja PESAT sedang memberikan pakan ternak kepada sapi-sapi yang diperoleh dari program kemitraan petani sekitar tambang dan lahan PESAT sendiri. Didokumentasikan oleh peneliti pada 15/02/2019.

Niat baik KPC (PESAT) untuk memperbaiki kehidupan komunitas tersebut dapat terlihat dari program kemitraan ini, yang nantinya KPC memperoleh pengakuan dari masyarakat bahwa hubungan kemitraan dari program CSR PESAT tersebut berhasil, "Perusahaan kan harus mengeluarkan CSR. Dapat pengakuan dari masyarakat berarti program ini berjalan" (Hasil wawancara, informan kepala operasional lahan pascatambang, Pak Rangga Lawe, 11 Februari 2019). Hal ini seringkali dilakukan perusahaan terutama yang bergerak dalam bidang industri ekstraktif untuk memperoleh pengakuan dan tetap dapat menjalankan perusahaan pertambangan tersebut dengan menjalankan patronase atau kemitraan agar perusahaan memeroleh SLO (Social License to Operate) (Gardner, 2016: 129).

Tidak hanya Desa Swarga Bara yang melakukan hubungan kemitraan dengan PESAT, Desa Singa Gembara juga terlibat dalam kemitraan dan di setiap bulannya dapat memasok pakan sebesar empat ton jagung ke PESAT (Sustainability Report KPC, 2016: 129). Melalui BUMDes Gembara Prima, Desa Singa Gembara, kelompok tani di desa tersebut juga dapat meningkatkan potensi ekonomi kelompok tani, dan bahkan dapat meningkatkan produksi rumput gajah sebagai pakan ternak sapi tersebut, hingga menambah anggota bagi kelompok tani di Desa Singa Gembara (Sustainability Report KPC, 2016: 129). Hingga saat ini model atau program mengenai kerja sama dalam hal memasok pakan dengan para petani di sekitar pertambangan ini yang masih bertahan. Namun, dalam perjalanannya, di tahun 2017, program kemitraan ini mengalami penurunan dalam jumlah mitra kerja.

Penurunan tersebut dikarenakan dalam sistem kemitraan yang digunakan oleh PESAT adalah dengan menggunakan sistem invoice (piutang). Sistem tersebut rupanya membuat para petani musiman tidak mampu mengikuti sistem yang diterapkan oleh perusahaan. Hal tersebut 
dikarenakan petani telah memiliki pola kebiasaan mereka sendiri dalam bertani. Apabila telah memanen salah satu hasil pertaniannya, maka mereka pada umumnya langsung dibayar di muka saat itu juga. Sistem piutang tersebut juga dikeluhkan oleh beberapa petani di Desa Swarga Bara, yang merasa keberatan apabila petani harus dibayar per bulan (menggunakan sistem invoice), sehingga membuat para petani secara umum tidak dapat mengikuti pola kerja perusahaan (PESAT),

"Petani ini kan mau-nya ada barang ada duit. Karena kita ini kan butuh duit, mau beli sayur, mau beli garamkah. Kalo nunggu sebulan baru ada duitnya makan apa selama sebulan itu kan. Kita butuh makan, butuh segala-galanya terus, persoalannya kita butuh pupuk, bibit dapat semua, racun, itu semua harus beli cash semua, ndak ada yang pake sistem invoice jadi kalau kita sebulan gak dibayar, mau beli racun pake apa," (Hasil wawancara, informan PM, 8 Februari 2019).

\begin{tabular}{cllll}
\hline No & Nama Supplier & Jenis Supplier & Jenis Hijauan & Asal \\
\hline 1 & $\begin{array}{l}\text { BUMDes Gembara } \\
\text { Prima }\end{array}$ & BUMDes & Rumput gajah & Desa Singa Gembara \\
\hline 2 & Berdikari II & $\begin{array}{l}\text { Kelompok Tani } \\
\text { Sangatta Selatan }\end{array}$ & Tebon Jagung & - \\
\hline 3 & Pak Iwot & Pribadi & Rumput gajah & Desa Sangatta Utara \\
\hline 4 & Pak Maryono & Pribadi & Rumput gajah & Desa Swarga Bara \\
\hline 5 & Pak Johanes & Pribadi & Rumput gajah & Desa Singa Gembara \\
\hline 6 & Pak Yacob & Pribadi & Rumput gajah & Desa Singa Gembara \\
\hline 7 & Pak Taufik & Pribadi & Rumput gajah & Desa Teluk Lingga \\
\hline
\end{tabular}

Tabel 1 Tabel setelah tahun 2017 tentang para pemasok (HMT/Hijauan Makanan Ternak) dari masyarakat sekitar tambang. ${ }^{1}$

Tabel 1 menunjukkan bagaimana perkembangan kemitraan PESAT, yang rupanya mengalami penyusutan. Pada tahun 2016 ketika kemitraan ini diinisiasi, PESAT mampu mengumpulkan mitra kerja berjumlah 17 petani (Sustainability Report KPC, 2016: 128). Pada tahun berikutnya, 2017, tinggal tujuh petani yang masih memasok pakan ternak ke PESAT. Menariknya, kelompok tani di Desa Singa Gembara melalui BUMDes tetap bertahan dalam memberlakukan sistem invoice (petani memberlakukan sistem piutang ke PESAT). Desa Singa Gembara memanfaatkan BUMDes Gembara Prima untuk mengantisipasi keberadaan mekanisme invoice yang dilakukan oleh PESAT. BUMDes di sini menjadi mediator (perantara) bagi para petani yang ingin memasok ke PESAT. BUMDes sebagai penengah dari persoalan sistem invoice (piutang kepada perusahaan) adalah cara yang efektif untuk mengakomodir para petani yang perlu mendapat bayaran langsung dari perusahaan. Hal tersebut juga sempat direncanakan oleh BUMDes Swarga Bara dan pemerintah desa lainnya.

Alhasil, hal tersebut tidak membuat petani bertahan untuk terus memasok pakannya kepada PESAT melalui BUMDes, sebab masih adanya permasalahan lain seperti harga yang ditawarkan oleh PESAT tidak memberikan keuntungan yang signifikan kepada para petani, dengan harga rumput gajah Rp 700,- per kilogram dan jagung Rp 1.000,- per kilogram. Menurut beberapa petani di Desa Swarga Bara, apabila jagung dijual ke pasar akan lebih memiliki nilai ekonomi yang lebih tinggi daripada ke PESAT. Di pasar, mereka dapat menjualnya dengan harga Rp 5000,- per kilogram, sedangkan di PESAT mereka hanya memperoleh Rp 1000,- per kilogram.

\footnotetext{
${ }^{1}$ Data diperoleh melalui bagan statistik pabrik pakan mini PESAT (16/02/2019) dan ditambah dengan wawancara Pak Asrianto, kepala Pabrik pakan mini mengatakan hanya tinggal Pak Yacob dan Pak Taufik yang menyuplai pakan ke PESAT, lainnya dinon-aktif-kan oleh PESAT di tahun 2019 atas alasan petani mulai tidak merasa diuntungkan (18/02/2019).
} 
"Kalau memang betul-betul petani, saya nanam jagung aja di lahan saya itu misalnya satu hektar itu, taruhlah panennya kalau maksimal, kalau bagus, tiga ton kan. Tiga ton kita jual lepas, maksudnya di pasar, itu Rp 5000,- per kilo, jadi kan berapa juta kalo sekali panen kan," (Hasil wawancara, informan PM, 8 Februari 2019).

Dari sini terlihat bagaimana rasionalitas para petani dan juga kesadaran mereka agar dapat memperoleh keuntungan lebih dari hasil panennya, dan saat ini para petani pun mengetahui peluang yang ada di pasar jauh lebih memberikan keuntungan daripada harus memasok ke PESAT. "Kan petani sekarang tidak bodoh-bodoh amat juga. Mereka punya hitung-hitungan," (Hasil wawancara, informan PM, 8 Februari 2019). Dari kasus ini, terlihat ada dua alasan mengapa petani memilih keluar dari kemitraan, yakni, pertama, sistem invoice yang dirasa memberatkan petani dan, kedua, harga yang diterapkan oleh PESAT dinilai terlalu rendah.

PESAT mula-mula dikembangkan atas kesepakatan antara pemerintah dan KPC melalui forum MSH-CSR dan juga menyesuaikan dengan dokumen RPT. Kemudian, setelah diupayakan dibangun PESAT, KPC memandang perlu ada program "pembangunan" bagi masyarakat yang berada di sekitar tambang. Kasus ini setidaknya menunjukkan bahwa didirikannya PESAT hingga mampu dapat mencanangkan program kemitraan dengan masyarakat tani di sekitar tambang rupanya lahir dari kepentingan program pembangunan top-down (Escobar, 1995: 44) antara pemerintah dan KPC. Masyarakat lokal di sini tidak terlibat secara langsung dalam rencana didirikannya PESAT. Oleh karena itu, sebuah interpretasi lain dapat dimungkinkan dalam memandang perusahaan tambang yang berupaya "membangun" masyarakat yang hidup di sekitar tambang.

"Pembangunan" yang dilakukan oleh KPC melalui program kemitraan PESAT tidaklah sekadar sebagai program "pembangunan" yang mengupayakan perbaikan kehidupan masyarakat di sekitar tambang, melainkan seperti yang dikatakan oleh Foucault mengenai "instrument-effects", bahwa program yang berjalan dalam waktu yang bersamaan juga memungkinkan adanya praktik kekuasaan birokrasi terhadap suatu populasi (masyarakat) (Sydow, 2016: 219). Maka dari itu, program kemitraan PESAT menjadi dipandang tidak hanya sebagai tanggung jawab sosial (CSR) yang perlu dijalankan oleh perusahaan atau sebagai "penebus dosa" (redemption) (Graeber, 2011: 379) akan kerusakan lingkungan, melainkan juga sebagai cara agar memperoleh SLO (Social Lisence to Operate) --pengakuan dari masyarakat. Hal ini dapat diartikan pula bahwa KPC menjalankan praktik-praktik kekuasaan untuk memperoleh kontrol terhadap suatu masyarakat (Sydow, 2016: 221).

"By creating cohesion and local bonds with actors of the community, companies can gain strength. Thus CSR, rather than being a philantrophic and altruistic act, offers mining companies a way to increase their agency and control"

(Dengan menciptakan kohesi dan ikatan lokal dengan para aktor dalam suatu komunitas, perusahaan dapat memeroleh kekuatan. Dengan demikian, selain menjalankan peran filantropis dan altruistiknya, CSR juga menjadi sebuah jalan bagi perusahaan tambang untuk meningkatkan pengaruh dan kontrolnya (Sydow, 2016: 221).

Perusahaan yang dipandang sebagai agen pembangunan (KPC) seringkali juga tidak melihat struktur dinamika kehidupan yang berada di masyarakat, "Intentional plans interacted with unacknowledged structures and chance events to produce unintended outcomes which turn out to be intelligible..." (Rencana yang disusun itu bertemu dengan struktur-struktur dan peluang-peluang yang luput dari perkiraan sehingga kian memperkuat kegagalan) (Ferguson, 1994: 20). Hal ini disebabkan oleh program pembangunan dengan skema top-down, yang berarti bahwa PESAT yang dicetuskan oleh KPC bersama pemerintah tidak sesuai dengan pola kehidupan masyarakat lokal. Pasalnya, masyarakat sendiri memiliki struktur dan pola kehidupannya yang juga berbeda dan belum tentu sesuai dengan jalan kepentingan KPC dan pemerintah atas program swa-sembada sapi. Kelalaian ini mengakibatkan dampak yang tidak diinginkan (unintended effects) seperti tidak berjalan baiknya program kemitraan 
tersebut. Pada akhirnya, para petani di beberapa desa pun memutuskan untuk meninggalkan kemitraan karena mereka tidak diuntungkan dalam program tersebut.

\section{KESIMPULAN}

CSR (Corporate Social Responsibility) sebagai wujud kepedulian dan tanggung jawab sosial perusahaan kepada masyarakat di sekitar tambang. Korporasi tambang kemudian berperan sebagai surrogate state (negara dalam negara) karena perannya yang "merepresentasikan" pemerintah dalam agenda pembangunan. KPC (Kaltim Prima Coal), telah berupaya berperan aktif dalam kegiatan-kegiatan di luar aktivitas menambang dengan slogan yang berbunyi "more than mining" (tidak sekadar menambang), dalam artian bahwa program CSR menjadi bentuk kontribusi pembangunan dari KPC kepada masyarakat di sekitar tambang dan juga strategi menjamin keberlanjutan usaha pertambangan. Memulihkan lahan pascatambang seperti yang dilakukan oleh KPC tidak semata-mata sebagai upaya membangun citra yang baik, melainkan juga dapat membangun diskursus baru yang mampu membuka ekonomi alternatif di luar kegiatan menambang. Salah satunya seperti program PESAT yang diletakkan sebagai program sosial (pemberdayaan) untuk masyarakat tani di sekitar tambang. Masyarakat ternyata tidak pasif dalam merespons aktivitas korporasi tambang di sekitar mereka. Mereka terus berupaya secara aktif agar dapat mengakses sumber daya yang dimiliki oleh perusahaan tambang dalam "tuntutan" mereka atas bantuan-bantuan dari dana CSR. Masyarakat akan menilai atau merespons negatif apabila sebuah program yang diimplementasikan tidak sejalan dengan kebutuhan mereka, seperti kasus program pemulihan lahan pascatambang yang bernama PESAT. Program kemitraan yang dijalankan PESAT dalam perkembangannya tidak berjalan dengan baik sebagai upaya korporasi untuk memberdayakan para petani lokal. Terlihat respons aktif para petani, mereka akan meninggalkan program apabila mereka tidak diuntungkan atas program tersebut. Oleh karena itu, program PESAT seharusnya menjadi program unggulan karena ada dua dampak yang bisa dimunculkan; pertama, ranah lingkungan yang mampu menaikkan citra korporasi tambang yang ramah lingkungan. Kedua, ranah ekonomi yang dapat memberdayakan masyarakat. KPC bisa mengatur dinamika perekonomian di lokasi tambang. Bahkan, negara pun secara tidak langsung menggantungkan diri pada perusahaan agar juga dapat melancarkan program pembangunan yang dicanangkan pemerintah sendiri. CSR kemudian juga perlu selaras dengan arah pembangunan pemerintah. Skema PESAT sebenarnya cenderung sebagai pola "pembangunan" top-down, yang berarti diberikan dari atas (pemerintah dan korporasi tambang) ke bawah (masyarakat lokal). Melalui skema seperti ini terkadang struktur dan dinamika masyarakat terabaikan dalam perencanaan pembangunan yang telah disusun oleh pemerintah-negara dan korporasi tambang. Kiranya sangat perlu untuk mengkritisi skema pembangunan top-down tersebut karena seringkali melalaikan pola atau struktur kehidupan masyarakat lokal yang menjadi target pembangunan. Oleh karena itu, masyarakat lokal perlu dilibatkan sejak awal dalam perencanaan pembangunan agar nantinya dapat selaras dengan kebutuhan dan struktur kehidupan sosial masyarakat lokal.

\section{DAFTAR PUSTAKA}

Ariningsih, E. (2014). Kinerja Kebijakan Swasembada Daging Sapi Nasional. Forum Penelitian Agro Ekonomi, Volume 32, No. 2.

Ashari, dkk. (2012). Dinamika Program Swasembada Daging Sapi: Reorientasi Konsepsi dan Implementasi. Analisis Kebijakan Pertanian. Volume 10, No. 2, halaman 181-198.

Biggs, D. (2018). Footprints of War: Militarized Landscapes in Vietnam. Seattle: University of Washington Press.

Brewer, J. D. (2000). Ethnography. Buckingham: Open University Press.

Devi, B., dan \& Prayogo. (2013). Mining and Development in Indonesia: An Overview of the Regulatory Framework and Policies. IMC4DC-International Mining for Development Centre, Action Research Report.

Dolan, C., \& Rajak, D. (2011). Introduction: Ethnographies of Corporate Ethicizing. Focaal-Journal of Global and Historical Anthropology 60, pg. 3-8. doi:10.3167/fcl.2011.600101. 
Escobar, A. (1995). Encountering Development: The Making and Unmaking of the Third World. New Jersey: Princeton Press.

Ferguson, J. (1994). The Anti-politics Machine: "Development", Depoliticization, and Bureaucratic Power in Lesotho. Minneapolis: University of Minnesota Press.

Gardner, K. (2016). "Disconnect Development: Imagining Partnership and Experiencing Detachment in Chevron's Borderlands". Dalam Dolan, Catherine dan Dinah Rajak [Ed]. (2016). The Anthropology of Corporate Social Responsibility. First published in 2016 by Berghahn Books. Hlm 128-151.

Graeber, D. (2011). Debt: The First 5,000 Years. New York: Melville House.

Granovetter, M. (1985). Economic Action and Social Structure: The Problem of Embeddedness. American Journal of Sociology 91:481-510.

Hammersley, M., \& Atkinson, P. (2007). Ethnography: Principles in Practice. London: Routledge Taylor \& Francis e-library.

Kaltimprov. (2018). Program Dua Juta Sapi Tahun 2018. https://kaltimprov.go.id/berita/kaltimmenjadi-sumber-ternak-nasional. Diakses pada 22 Januari 2021.

Mauss, M. (1967). The Gift: Forms and Functions of Exchange in Archaic Societies. New York: W. W. Norton \& Company, Inc.

Meutia, I., \& Liliana. (2017). Pengelolaan Keuangan Dana Desa. Jurnal Akuntansi Multiparadigma JAMAL, Volume 8, Nomor 2.

Perreault, T. (2012). Extracting Justice: Natural Gas, Indigenous Mobilization, and the Bolivian State. dalam Sawyer, Suzana dan Edmind Terence Gomez [ed]. (2012). The Politics of Resource Extraction : Indigenous People, Multinational Corporation, and the State. Hampshire: PALGRAVE MACMILLAN.

Rajak, D. (2011). In Good Company: An Anatomy of Corporate Social Responsibility. Stanford, CA: Stanford University Press.

Sawyer, S., \& Gomez, E. T., [ed]. (2012). The Politics of Resource Extraction: Indigenous People, Multinational Corporation, and the State. Hampshire: PALGRAVE MACMILLAN.

Sari, dkk. (2015). Pengelolaan Alokasi Dana Desa dalam Perspektif Pemberdayaan Masyarakat. Jurnal Administrasi Publik (JAP) Universitas Brawijaya, Vol. 3, No. 11.

Suryanto. (2013). Implementasi Corporate Social Responisibility (CSR) dalam Kerangka Good Local Goverannce (Studi Kasus Pelaksanaan MSH-CSR di Kabupaten Kutai Timur). Jurnal Borneo Administratir Vol. 9 No. 3 - 305 - 328.

Sydow, J. (2016). Global Concepts in Local Context: CSR as "Anti-Politics Machine" in the Extractive Sector in Ghana and Peru. dalam Dolan, Catherine dan Dinah Rajak [ed]. 2016. Anthropology of Corporate Social Responsibility. New York: Berghahn Books.

Sustainability Report PT. KPC. (2017). KPC untuk Indonesia. Gedung M2 PT. Kaltim Prima Coal, Mine Site Sangatta, Kutai Timur, Kalimantan Timur.

Sustainability Report PT. KPC. (2016). Nyalakan Semangat Bersama. Gedung M2 PT Kaltim Prime Coal, Mine Site Sangatta, Kutai Timur, Kalimantan Timur.

Van Teijlingen, K. (2016). The 'will to improve' at the mining frontier: Neo-extractivism, development and governmentality in the Ecuadorian Amazon, Extr. Ind. Soc. http://dx.doi.org/10.1016/j.exis.2016.10.009.

Warnaars, X.S. (2011). Why be poor when we can be rich? Constructing responsible mining in El Pangui, Ecuador. Resources Policy. doi:10.1016/j.resourpol.2011.10.001.

Welker, M. (2014). Enacting the Corporation: An America Mining Firm in Post-Authoritarian Indonesia. California: University of California Press.

----- (2009). Corporate Security Begins in the Community: Mining, the Corporate Social Responsibility Industry, and Environmental Advocacy in Indonesia. Cultural Anthropology, Vol. 24, Issue 1, pp. 142-179 by the American Anthropological Association (AAA).

Yanagisako, S. J. (2002). Producing Culture and Capital: Family Firms in Italy. Princeton, NJ: Princeton University Press. 